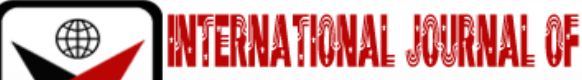

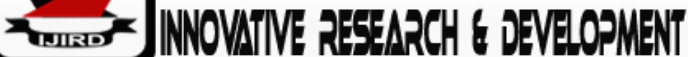

ISSN 2278-0211 (Online)

\section{Corporate Governance and Sustainability Reporting: The Controlling Effect of Company Size and Age in Selected Listed Firms in Nigeria}

\author{
Owolabi, Sunday Ajao \\ Professor, Department of Accounting, Babcock University, Ilisan Remo, Nigeria \\ Olayinka, Olalekan Moses \\ Ph.D. Candidate, Department of Accounting, Babcock University, Ilisan Remo, Nigeria
}

\begin{abstract}
:
As a result of the deficiency of traditional financial reporting in information disclosure to stakeholders, the need for sustainability reporting has become a global phenomenon. This study investigated the controlling effect of company size and company age on corporate governance and sustainability reporting in selected quoted companies in Nigeria The study adopted ex-post facto research design. The population of study comprised 169 quoted companies on the Nigerian Stock Exchange (NSE) as at December 31, 2019. A sample of 42 quoted companies was selected through stratified and purposive sampling techniques for the period of 10years (2010-2019). Data were extracted from published audited annual report and accounts of the sample companies. Data were analyzed using descriptive and inferential (Multiple regression) statistics.

The findings revealed that company size and company age controlled the effect of CG on sustainability reporting in Nigeria (Adj $R^{2}=0.378$, Wald-Stat $=447.64, p<0.05$ ). In addition, there is evidence that board size, board independence, female director, board ownership, company size and company age have significant relationship with sustainability reporting ( $B S=0.349$, $t$-test $=3.283, p<0.05, B I=0.336, t$-test $=2.087, p<0.05, F D=1.208, t$-test $=12.411$, $p<0.05, B O=0.004, t$-test $=7.837, p<0.05, C Z=0.108, t$-test $=6.328, p<0.05$ and $C A=0.154, t$-test $=3.395, p<0.05)$. However, CEO duality do not have significant relationship with the sustainability reporting $(C D=0.113, t$-test $=1.668$, $p>0.05)$

The study concluded that company size and company age controlled the effect of corporate governance on sustainability reporting. The study recommended that the shareholders should include more female and independent directors on board as it promotes sustainability reporting practices. Also, the shareholders are advised to include more directors with share ownership as it enhances sustainability reporting practices and CEO duality should be avoided as it does not significantly impact $S R$.
\end{abstract}

Keywords: Board independence, board ownership, board size, CEO duality, female directors, legitimacy theory, sustainability reporting

\section{Introduction}

As a result of the deficiency of traditional financial reporting in information disclosure to stakeholders, the need for sustainability reporting has become a global phenomenon. Sustainability reporting enhances the quality of financial reporting by meeting the needs of diverse users of corporate information. Globally, economies are interconnected and interdependent on one another, and as such companies are expected to design policies and strategies that will promote transparency in reporting practices (Mudiyanselage\&Swarnapali, 2018). The current traditional accounting system was criticized because of its inadequacy in reporting the total picture of firms impacts and the efforts at achieving improvements (Schaltegger, Etxeberria and Ortas, 2017).

Sustainability reporting assists organizations in disclosing its ethical compliance and efforts at promoting social norms so as to promote legitimacy and acceptance by the people (Han \&Kuhnen, 2013; De Villiers \&Maques, 2016). Also, due to the fact that capital investment decision and corporate objectives are long-term in nature, managers need to demonstrate responsibility by reporting on sustainability in a dynamic environment (Waddock\& Graves, 1997).

Herda, Taylor and Winterbotham (2012) conducted a study to examine the effect of board independence on the sustainability practices in the U.S. firms. Descriptive statistics showed that 242 out of 500 Large companies in the United States representing $48 \%$ published standalone sustainability reports and $80 \%$ of directors on board were independent directors. In a bid to further strengthen this culture of voluntary compliance, the USA and Canada, Security and Exchange Commission (SEC) issued guidance on the need for more disclosures in response to institutional and individual concerns. 
The concerns range from litigation, reputational damage, operational disruption and regulatory sanctions (Nazari, Herremans \& Warsame, 2015).

Companies in Europe were complying with the Global Reporting Initiative (GRI) by voluntarily including nonfinancial information in their annual reports and accounts. To further institutionalize this practice, European Parliament and the Council published the Directive 2014/95/EU regarding the disclosure of non-financial information. This Directive requires that firms with employees' population above 500, total balance sheet of 20 million Euros or a turnover of 40 million Euros or publicly quoted companies are mandated to publish annually their accounts with issues relating to environmental, social impacts and governance (Carrillo, De La Cruz \&Chicharro, 2019).

According to White (2012), Johannesburg Stock Exchange (JSE) was the first exchange in Africa to have mandated integrated reporting in a single/separate report for quoted companies since March, 2010. The first integrated reporting framework was published in 2013. In a study conducted by Ngakwe, Ganda and Akinyemi (2014), the findings revealed that independent board members have more influence on sustainability reporting in South Africa. In South Africa, 43\% of companies have three (3) or more independent directors on board while $57 \%$ have one (1) or two (2) independent directors on their board.

In Nigeria, scholars such as Isa, 2014; Odoemelam and Okafor, 2018 and Aliyu, 2018 considered mainly the impact of corporate governance on environmental sustainability reporting using different sectors of the economy such as food and beverage sector and non-financial firms. Most studies used environmental sustainability and other disclosure indices but the studies did not consider other aspects of sustainability reporting such as economic and social sustainability reporting. The Nigerian Stock Exchange (2018) established Sustainability Disclosure Guidelines for the purpose of guiding public interest companies in sustainability reporting through the application of performance indicators in each of the economic, social and environmental issues in sustainability reporting.

Corporate Governance involves the process by which organizations are regulated and directed to ensure the maximization of shareholders' wealth and all organizations are expected to practice good corporate governance (Steger \&Amann, 2008; Rahman \& Islam, 2018). Corporate governance sets out the activities of the board and the approach of relating with the shareholders, managers and including the external parties such as auditors, regulatory authorities and other stakeholders (Tricker, 2012). The Corporate governance structure serves as a guide in the devolution of authority and responsibilities among the different levels of organization such as board, managers and shareholders (Ho, 2005). It can be inferred that corporate governance lays down guidelines and procedures for resolving financial and non-financial issues in an organization.

Therefore, sound corporate governance practices can result into sustainability reporting that will lead to the achievement of long-term corporate objectives. Therefore, this study examined the controlling effect of company size and age on corporate governance and sustainability reporting in selected listed companies in Nigeria.

\section{Literature Review}

The World Council for Sustainable Development (2002) defined corporate sustainability as the responsibility of business to contribute to sustainable economic development, with the aim of improving the quality of life of employees and their family, the well-being of the local community and the society in general. In 2011, KPMG conducted a survey on corporate sustainability reporting and found that out of the 250 largest company in the world, 95\% conduct corporate sustainability reporting. This is an indication that corporate sustainability is growing in acceptance globally.

Also, Sustentare (2010) defined corporate sustainability as the ability of the entity, through its governance structure and processes to keep the value of the ecosystems by reducing pollution level and improving the natural resources, improve the society by supporting the host community and its people and by enhancing economic development through wealth distribution, fair emolument and respect for obligations to third parties. This definition posits that sustainability and corporate governance are inextricably intertwined and that for a company to exhibit sustainable behaviour, it is expected to implement policies that will serve the interest of shareholders, the people and the environment.

Krechovska and Prochavskova (2014) posited that corporate sustainability can be defined as the ability of a company through its corporate governance practices, to influence the ecosystem, the society and the economy positively. Corporate governance practices play a pivotal role in the economic, social and environmental dimension of sustainability. Furthermore, Mahmood, Kouser, Ali, Ahmad and Salman (2018), opined that corporate sustainability refers to the ability of the company to create a long-lasting value that can meet the needs of all stakeholders.

In the same vein, Perrini and Tencati (2006) defined corporate sustainability as the ability of the company to create value over long-term period of time. It then goes beyond communication between the entity and the stakeholders but it must be with value creation intention on the part of the management. Corporate sustainability is also defined as a strategic approach that focuses on organization's productivity, effectiveness and efficiency (Kocmanova, Hrebicek\&Docekalova, 2011). In other words, corporate sustainability has to be integrated into the main stream policy of the organization to deliver maximum value.

Corporate sustainability focuses on ensuring equity within generation and between generations (Blowfield\& Murray, 2008). Companies align with the principle of value preservation initiative by publishing sustainability report which serves as communication tool between the business entity and diverse stakeholders (Sawani, Zain \&Darus, 2010). Furthermore, corporate sustainability is viewed as a strategic process which focuses on creating value for owners effectively and efficiently from economic, social and environmental dimensions (Hrebicek\&Docekalova, 2011).

It is the responsibility of the management to balance the expectations from the three dimensions mentioned above. It confers legitimacy on the organization as it reveals the conformity with social norms (De Villiers \& Marques, 
2016). Corporate sustainability can only enhance creation of long-term wealth for shareholders if sustainable development ideology is incorporated into business strategy. Dyllick and Hockerts (2002) suggested that enterprise should design corporate sustainability as follows:

- Ensure efficient and effective utilization of organization's resources.

- Manage the expectations of stakeholders by eliminating the influence of information asymmetry.

- Align profitability and sustainable development goal to achieve synergy

Therefore, corporate sustainability can be defined as the demonstration of responsibility by the reporting entity by ensuring the interest of all the stakeholders are accommodated in their long-term business strategy.

\subsection{Board Size}

According to Fama (1980), the board of directors are component part of internal governance mechanisms through which decisions and actions of managers can be monitored and controlled. The board of directors acts as a control instrument that limits agency problems between executive management and shareholders (Hermalin\&Weisbach, 1991). The board gives direction to the organization by taking critical decisions to enhance business value and minimize the possible abuse of powers by the top management. According to Dehaene, Vuyst and Ooghe (2001) board size is the total number of directors serving on the board of a firm which is determined by firm size and nature of business. Also, Isik and Ince (2016) defined board size as a critical part of corporate governance system that plays a major role in the effective functioning of the board. Board cannot function properly without appointing well experienced people to occupy it.

Board size is the number of directors on the board which includes the executive and the independent (non-executive) directors. The number of directors on board varies from country to country according to the culture and size of the company (Zabri, Ahmad \&Wah, 2016). Therefore, there is no globally recommended board size. Some companies adopt a small board size with the orientation that monitoring and decision making would be faster and more rigorous while some believe that larger board size will engender more robust discussion that will enhance quality of decision making (Olayiwola, 2018).

Lipton and Lorch (1992) opined that the preference for smaller board size emanated from organizational and technological change which necessitates cost reduction to remain competitive. Globally, organizations compete for larger share of the market and appropriate pricing is very critical to achieve this objective. Also, the problem of coordination of a larger board outweighs its benefits (Jensen, 1993). In the same vein, Hermalin and Weisbach (2003) argued that there is tendency for a larger board to be less effective than smaller board because larger board can increase agency problem as some directors' contribution become insignificant in board decisions.

However, a very small board size lacks the necessary expertise and experience that can be derivable from a larger board size. Larger board size has tendency for diversity in terms of skills, experience, gender and nativity (Dalton \& Dalton, 2005). Also, mismanagement and self-enrichment by the CEO and other directors are associated with smaller board. As a result of fewer number of directors on a smaller board, the directors may focus on decision making and ignore monitoring function which is a very critical function.

Though, the ideal board size varies from 5 to 16 directors depending on the company size, nature of business, and the complexity of the industry (Carnegie \& Napier, 2010; Momin\& Parker, 2013). According to Mahmood, Kouser, Ali, Ahmad and Salman (2018), quality performance is attainable by a larger board as a result of its capacity to acquire lowcost resources for the organization.

Furthermore, Hu and Loh (2018), posited that larger board size can reduce the dominance of the management by mitigating the influence of conflict of interest. A larger board is also a pool of experienced and resourceful people who can guide on sustainability issues. Larger board are likely to be abreast of trends in sustainability reporting through directors' network (Hu, et al, 2018). Also, Ajibolade and Uwuigbe (2013) concluded that a larger board is more effective in supporting the disclosure of social and environmental information to the stakeholders. It is expected that larger board can maintain independence from the management as a result of the number and thereby influence management to disclose more economic, social and environmental information.

Furthermore, Mojeed, Aziz and Saleem (2015) and Yaseen, Al-Amarneh and Iskandrani (2018) found a positive relationship between board size and the level of social sustainability disclosures. Also, Ghabayen, Mohamad and Ahmad (2016) found that there is a positive relationship between board size and disclosure of social responsibility in Jordanian banks. In the same vein, Akbas (2016) found that there is a positive relationship between board size and environmental disclosures in Turkey.

According to Sar (2018) companies with high corporate governance index such as larger board size are associated with superior sustainability performance. The limitation of the study is that the researcher did not differentiate between the small and large companies and this affected the outcome of the work.Alotaibi, Aburuman and Hussein (2019) concluded that banks with larger board size publish quality sustainability reports.

Therefore, a larger board has tendency to represent a wider range of stakeholders and promote their need for greater transparency which might influence the organizations' disclosure policies (Dias, Rodrigues \& Craig, 2017). This might be due to the skills, experience and knowledge acquired by the members on board of directors over the years. Also, appointment on board is due to the track record of honesty, integrity and hardwork. According to Mahmood, et al., (2018), the disclosure of voluntary information is driven by the size of the board.

\subsection{Board Independence}

Independent directors are the kind of directors who have no business or professional link with a company apart from being a member of the board (Ong et al, 2018). An independent director is a non-executive director who holds no 
substantial shares of the company. According to Jensen and Meckling, (1976) and Wang and Dewhirst, (1992), the presence of independent directors can assist in minimizing management excesses and maximize the interest of wider stakeholders.

Furthermore, Fama and Jensen (1983) opined that boards with a higher proportion of independent directors' work in the best interest of the minority shareholders in order to maintain their own good reputation in society. Though working in the best interest of a group of stakeholders at the expense of others may question the presence of independence directors.

The Cadbury Committee (1992) affirmed the need for a higher proportion of non-executive directors to executive directors on the board to enhance the robustness of the board decisions. In the same vein, Kesner and Johnson (1990), opined that independent directors are more vigilant and less tolerant to the reckless attitudes of management in incurring expenses. They tend to have a broader perspective on strategic management issues (Rupley, Brown \& Marshall, 2012). Also, independent directors are likely going to take more initiatives to enhance sustainability reporting as they also act as monitoring agent for management activities (Mahmood, et al, 2018).

In a nut shell, a board governance is expected to be stronger with higher number of independent directors and more robust sustainability disclosures. Several empirical studies have found a positive correlation between the proportion of independent directors on board and the extent of sustainability reporting. Mudiyanselage, et al, (2018) reported a positive and significant relationship between the proportion of independent directors and sustainability disclosures. $\mathrm{Hu}, e t$ al, (2018) also found an association between the independent directors on the board and likelihood of quality sustainability reporting. Rupley, et al, (2012), also reported positive correlation between the proportion of independent directors and the depth of sustainability disclosures.

However, Michelon and Parbonetti (2012) in their study, did not find any significant correlation between the proportion of independent directors and sustainability reporting but found a significant and positive correlation between proportion of influential community members on board and sustainability reporting. The essence of sustainability reporting is to disclose how the firm is utilizing resources in meeting the needs of shareholders, delivering satisfaction to employees and the people living in the locality and disclosing how the negative externalities is being minimized. From the previous studies reviewed, independent directors are expected to align with the interest of the wider group of stakeholders rather than the parochial interests of the management.

For the purpose of this study, board independence is measured by the proportion of independent directors to total number of directors on board.

\subsection{CEO Duality}

CEO duality exists when one person serves as both the CEO and the chairman of the board of directors of the same company (Rechner\& Dalton, 1991). Larcker, Richadson and Tuna (2007) are of the opinion that when corporate decisions are taken by two separate persons in CEO and chairman's position, agency problem will be resolved and performance of the firm improves. Though it makes the work easy but most of the frauds are committed due to the combination of the CEO and the chairman's positions (Beasley, Carcello and Hermanson, 1999). DorminguezSanchez, and Alvarez (2011) in analyzing the disclosure practices of Spanish companies in relation to a voluntary disclosure of information found that corporate disclosure was sufficient where the chairperson of the board is the same person as the CEO and this implies that there is a positive relationship between CEO duality and sustainability disclosure.

However, Fama and Jensen, (1983) argued that since CEO duality refers to the absence of separation of decision management and decision control, the board will be unable to effectively monitor and evaluate the CEO. Also, the implication is that, with this superior governance power the board can become less effective in its monitoring and controlling functions (Mallete\& Fowler, 1992). The excessive power can also threaten the reliability of information dissemination to other directors (Samaha, Khlif\&Hussainey, 2015).

Furthermore, Shamil, Shaikh, Ho and Krishnan (2014) posit that chief executive officer (CEO) duality tends to lead to the compromise of board independence. It also increases the information asymmetry problem as it supports the concealment of vital information from the independent directors (Mudiyanselage, et al, 2018). It can also lead to weak corporate mechanism and a doctored corporate disclosure.

In addition, Ong, et al, (2018) in their study of Australian resource industry argued that companies with Chief Executive Officer (CEO) duality disclose more sustainability information than companies which separate the role of CEO from the chairmanship position. Also, Carrillo, De La Cruz and Chicarro (2019) examined the European listed firms and concluded that CEO duality impact sustainability disclosure positively. Though, Villier, Naker and Staden (2011) posited that CEO duality has no significant impact on sustainability reporting.

However, Kula (2005) in Ajibolade, et al., (2013) concluded that CEO duality may weaken the system of checks and balances between the roles of CEO and chairmanship of the board. This may lead to conflict of interests and reduction of the potency of accountability and transparency. Khaldoon, Dea'a Al-Deen and Mahmood (2018) also argued that CEO duality weakens the effectiveness of the board in reporting sustainability. Hu, et al, (2018) also concluded that CEO duality is negatively associated with the quality of sustainability reporting.

For the purpose of this study, CEO duality is coded by " 0 " if CEO is also the chairman and " 1 " if the CEO and chairmanship functions are separated. 


\subsection{Female Director}

The inclusion of female directors promotes the quality of board and enhances the effectiveness of the management (Carter, Simkins\& Simpsons, 2003; Post, Rahman \&Rubow, 2011). According to Mahmood, et al, (2018), female directors are less economically inclined and more prone to helping mankind than their male counterparts.

Thereby making female directors to be less driven by short term personal agenda. Since sustainability reporting is a longterm phenomenon, the inclusion of women can positively impact the social sensitivity of an organization. The recognition of female director contributions is increasing (Rao, et al, 2012) as prior studies have highlighted the benefits of having women on board.

According to Huse and Solberg (2006), the inclusion women on board increases the preparation, the commitment and the diligence of the board while Adams and Ferreira (2009) posited that having women on board improves decision making process, increases board effectiveness that can result in better attendance and performance. Arayssi, Dah and Jizzi (2016) found that adequate women representation on the board enhances quality deliberations and ultimately influences the quality and integrity of sustainability reporting.

Furthermore, Garcia- Sanchez, Suarez-Fernandez and Martizez-Ferrero (2018) opined that board with greater female representation have tendency to report sustainability issues without technically suppressing facts or give misleading information intended to attract the attention of various stakeholders. This is also referred to as green reporting which means presenting biased information in an attempt to cover the true position as regards sustainability issues. Also, Birindelli, Dell' Atti, Ianuzzi and Savioli (2018) alluded to the fact that the presence of women on board significantly and positively influence economic, social and governance (ESG). The study however disagreed with critical mass theory by positing that inclusion of more than three (3) women board has negligible influence on sustainability performance. Specifically, Fenandez-Feijoo, Romero and Ruiz Blanco (2014) concluded that board with at least three (3) women report on corporate social responsibility which is an aspect of sustainability reporting. Also, Hyun, Yang, Jung and Hong (2016) confirmed that women on board positively influences corporate social responsibility rating of the organization if only the women are independent directors. The independence of the women on board is the only assurance that they will not succumb to pressures from other board members in supporting their personal agenda. Abu Bakar, Ghazali and Ahmad (2019) also concluded that women on board has significant impact on sustainability reporting and this is further supported by Mahmood, et al, (2018) that the presence of women on board influences the quality of management decision on sustainability reporting. This is further confirmed by Anazonwu, Egbunike and Gunardi (2018) that there is a significant relationship between women on board and sustainability reporting.

However, according to Kapotas (2010), the inclusion of women on board may not necessarily promote social responsibility as the quota of power allocated to women are lower than their male counterpart. In other word, minority will have their say and majority will have their way. Adeniyi and Fadipe (2018) concluded that there is no significant relationship between board diversity and sustainability reporting. By implication, the inclusion or non-inclusion of women on board has no significant impact on sustainability reporting. For the purpose of this study, female director is measured by number of female directors to total number of directors.

\subsection{Board Ownership}

According to Nasari, et al, (2015) board ownership are institutional and individual investors' who have major shareholdings in an organization and are concerned about the risk associated with operational problems business disruptions, meeting regulatory requirements and avoiding reputational damage that can reduce competitive advantage. Sustainability information appears to be germane to institutional owners because of the substantial nature of their investments.

Institutional ownership is a form of concentrated ownership which is measured by the percentage of shares held by institutions and or large investors. Ownership concentration is a critical aspect of corporate governance whether dispersed or concentrated one (Habib and Jiang, 2009; Shan, 2009). According Lakhal (2005), the institutional investors include suppliers of funds to financial markets such as insurance firms, pension funds and investment firms.

According to Patton and Baker (1987), board ownership can be defined as the concentration of equity ownership by some directors who are likely to objectively evaluate performance of the organization's performance by controlling the choices of the firm. Stock ownership aligns with best practices such as sustainability reporting so as to protect their investments.

Chang and Zhang (2015) opined that institutional ownership and ownership concentration have significant positive effect on voluntary environmental information disclosure. Rudyanto (2017) concluded that state ownership positively influences sustainability reporting while family ownership does not have any significant influence on sustainability reporting. This is possibly because the state focuses on public good while the family objective is to maximize shareholders value.

Masud, et al., (2018) posited that foreign and institutional ownership has a positive association with environmental sustainability reporting performance (ESRP) and also directors share ownership. However, according to Abu Qa'dan and Swaidan (2019), board ownership concentration and institutional ownership are negatively associated with corporate social responsibility. 


\subsection{Control Variables}

\subsubsection{Company Size}

The essence of control variable is to enhance the accuracy of the independent variables in regression to avoid spurious results. According to Mudiyanselage, et al, (2018), firm size and age are indication of organizational maturity. As a mature company, it is expected to disclose more voluntary information such as sustainability reporting to meet the diverse needs of stakeholders who have financial and non-financial interest in the firm.

A firm size can be defined as the ability of its productive capacity to produce sufficient quantity of products or variety of quality services to satisfy customers' needs (Saheen\& Malik, 2012; Vinasithamby, 2015). According to Aliyu (2018), company size represents visibility and financial capability to be socially and environmentally responsible. The capacity of the firm to report economic, social and environmental sustainability is expected to grow with size (Cormier and Magnan, 1999).

Kaen and Baumann (2003) identify three definitions of company size according to different theories. Technological theories defined company size as the production process, physical capital and economies of scale: Organizational theories defined company size as transactions cost, agency cost and span of control and institutional theories defined company size as legal system, anti-trust regulations, patent protection, market size and the development of financial market. Technological and organizational theories defined company size focusing on the internal capacity while institutional theories defined company size in terms of external regulatory framework and how it affects a firm.

Nazari, et al., (2014) defined firm size as the outstanding of total assets of the firm at the end of the year that is unimpaired. Also, Ghazali (2010) defined company size as the total value of assets of the organization. Shuaibu, Ali and Amin (2019) defined company size as the expansion of company's operation measurable in terms of assets, employment and market capitalization.

Therefore, company size is an important consideration in relation to sustainability reporting because larger companies are exposed to more public scrutiny than small firms (Hassanein\&Hussainey, 2015). Consequently, firms with larger size are expected to disclose more future oriented information to sustain the competitive edge and increase its market size. Therefore, the drive to use corporate governance to enhance sustainability reporting can be controlled by firm size. Company size is measured by the logarithm of total assets as it has been used in previous studies (Ghazali, 2010; Nazari, et al., 2014; Wijethlake, et al., 2015; Buallay, et al., 2018; Rudyanto\&Siregar, 2018; Aliyu, 2018 \&Mudiyanselage, et al., 2018).

\subsubsection{Company Age}

According to Shumway (2001), company age can be defined as the number of years of incorporation till date. In the same vein, Gitzmann (2008) and Pickering (2011) view a company as a legal entity which is borne at incorporation. At that point, certificate of incorporation with a unique number is issued by Corporate Affairs Commission (CAC) and Tax Identification Number (TIN) is issued by Federal Inland Revenue Service (FIRS) in recognition of the legal status of the company. Buallay, et al., (2010) defined company age as the number of years since the company was incorporated and not when its shares were listed. For the purpose of this study, company age is measured by the number of years of listing on the Nigerian Stock Exchange (NSE).

However, Ilaboya, Ohiokha and Izevbekhai (2016) opined that a company is borne when its shares are listed on the floor of Nigerian Stock Exchange (NSE) for trading purpose. This definition is supported by some researchers such as Ling and Sultana, (2015), Mudiyanselage, et al, (2018) and Alotaibi, Aburuman and Hussein, (2019). Thus, the hypothesis of this study is stated below:

- Ho1: Company size and company age do not significantly control the relationship between corporate governance and sustainability reporting in selected quoted companies in Nigeria.

\subsection{Legitimacy Theory}

Legitimacy theory was propounded by Dowling and Pfeffer in 1975. It was derived from the concept of organization legitimacy and it was defined as a condition which exists when entity's value system aligns with the value system of the larger society where the entity is located otherwise the entity's legitimacy is threatened if there is a disparity in those values (Lindbloom, 1993). The assumption of the theory is that there is a "social contract" between the company and the society and it is expected that economic and social benefits will be distributed to the people (Deegan, 2002). As a result of this, organization strive to comply with the norms of the societies of operation and voluntarily report its activities if the management perceives that it is necessary to satisfy the public. The theory further assumes that a company has no right to exist unless its values are being perceived as delivering quality benefits to the society.

The supporters of this theory are Patten (1992) and Deegan (2000) as they stated that sustainability reporting has tendency to reduce regulatory risk and minimize resistance by other stakeholders who are affected by the activities of the organization. Organizational legitimacy is a form of approval to operate in a peaceful business environment. Accordingly, the idea of the legitimacy theory resembles a social contract between the company and the society (Magness, 2006). Guthrie and Packer (1989) in supporting this theory affirmed that the disclosure practices of firms' decision or actions are legitimate to the extent that it considers environmental factors such as economic, social and political issues. This shows that legitimacy theory confers societal acceptability on the conduct of corporate organizations. Since the major objective of financial reporting is to provide users with information that help in decision-making (i.e., satisfying social interests), the theory has been incorporated into accounting studies as a means of explaining what, why, when and how certain items are addressed by corporate management in their communication with stakeholders. 
Mobus (2005) and Owen (2008) criticized the abstract nature of legitimacy theory as a theory that just explained managerial motivation without any specific idea about how disclosures can promote transparency and accountability towards stakeholders that are non-providers of capital. Thus, making it difficult for the management to understand the mechanism of voluntary disclosure.

Therefore, organizations are expected to demonstrate responsibility by reporting on sustainability. For an organization to continue to enjoy legitimacy and existence, corporate disclosures should recognize the three dimensions of economic, social and environmental sustainability reporting (Gray, Kouhy\& Lavers, 1995; Hooghiemstra, 2000). This is the theoretical framework for this study.

\section{Methodology}

\subsection{Sample Selection}

169 firms were listed on the Nigerian Stock Exchange as at 31 December, 2019 out of which a sample of 42 firms was selected for period of 2010 to 2019. The period chosen is between the world economic meltdown of 2009 and Covid19 pandemic of 2020. The Nigerian Stock Exchange divided listed firms into 11 sectors of the economy as shown in Table 1 below. Stratified and purposive sampling techniques were used in selecting the sample. The rationale for the selection of the 42 companies is based on the following; first, the selected companies must have been listed for about 10 years or more, that is from 2010-2019. Second, the selected listed firms must have up-to date records, that is; they must have been publishing annual financial reports for the period. Third, the company must have been reporting components of sustainability reporting in the financial statement or standalone sustainability report for the period. Content analysis was done to extract data from the financial report of the sampled companies. The sample size is indicated in Table 1:

\begin{tabular}{|c|c|c|c|c|}
\hline S/N & Sectors & Listed Firms & Sampled Firms & $\begin{array}{c}\text { Of Sampled Firms Per } \\
\text { Sector }\end{array}$ \\
\hline 1 & Agriculture & 5 & 3 & 60 \\
\hline 2 & Conglomerate & 6 & - & 13 \\
\hline 3 & Construction/Real Estate & 8 & 1 & 18 \\
\hline 4 & Financial Services & 57 & 10 & 30 \\
\hline 5 & Health Care & 10 & 3 & 29 \\
\hline 6 & ICT & 7 & 2 & 5 \\
\hline 7 & Industrial Goods & 14 & 4 & 75 \\
\hline 8 & Natural Resources & 4 & 2 & 4 \\
\hline 9 & Oil and Gas & 12 & 9 & 33 \\
\hline 10 & Services & 25 & 1 & 25 \\
\hline
\end{tabular}

Table 1: Distribution of the Sample

Source: Nigerian Stock Exchange and Authors' Computation

\subsection{Model Specification and Measurement of Variables}

The model for the study is stated below:

$\mathrm{SR}_{\mathrm{it}}=\beta_{0}+\beta_{1} \mathrm{BS}_{\mathrm{it}}+\beta_{2} \mathrm{BI}_{\mathrm{it}}+\beta_{3} \mathrm{CD}_{\mathrm{it}}+\beta_{4} \mathrm{FD}_{\mathrm{it}}+\beta_{5} \mathrm{BO}_{\mathrm{it}}+\beta_{6} \mathrm{CZ}_{\mathrm{it}}+\beta_{7} \mathrm{CA}_{\mathrm{it}}+\mathrm{U}_{\mathrm{it}}$

Sustainability reporting (SR) is measured by the average of the aggregate of economic sustainability, social sustainability and environment sustainability in accordance with GRI-4. The performance indicators as disclosed in the Global Reporting Initiative (GRI-4). Disclosure guidelines was developed into a checklist with which the actual disclosure in the annual reports of the sampled firms were compared (Mahmood, et al., 2018). The approach used by Nazari, et al, (2015) was adopted for this study. The parameters of economic sustainability reporting are four (4), the score ranges from 0-1 depending on level of disclosure, the parameters of social sustainability reporting are seventeen (17) and the score ranges from 0-1 depending on the level of disclosure and the parameters for environmental sustainability reporting are twelve (12) and the score ranges from 0-1 depending on the level of disclosure in annual report. The average of the aggregate of the final score for economic, social and environmental sustainability represents the score for sustainability reporting. This method ensures equality in the weight irrespective of the number of indicators in each category. Board size (BS) was measured by the number of directors on board (Shamil, et al, 2014; Aliyu, 2018), Board Independence (BI) was measured by the proportion of independent directors to total number of directors (Mudiyanselage, et al, 2018), CEO duality (CD) was denoted as "0" if the chairman's role and Chief Executive Officer are performed by one person otherwise "1" (Liao, et al, 2015), Female director (FD) is measured by the number of female directors to total number of directors , board ownership (BO) was measured by the percentage of shares owned by directors (Wijethilake, 2015). Company size (CS) is measured by the logarithm of total assets (Aliyu, 2018; Mudiyanselage, et al, 2018) and company age (CA) is measured by the number of years of listing on the Nigerian Stock Exchange (Ling \& Sultana, 2015; Alotaibi, Aburuman\& Hussein, 2019). 


\subsection{Presentation of Regression Results}

\begin{tabular}{|c|c|c|c|c|}
\hline Variables & Coefficient & S.E & t-test & Prob. \\
\hline Constant & $-1.606^{* * *}$ & 0.157 & -10.215 & 0.000 \\
\hline BS & $0.349^{* * *}$ & 0.106 & 3.283 & 0.001 \\
\hline $\mathrm{BI}$ & $0.336^{* *}$ & 0.161 & 2.087 & 0.037 \\
\hline $\mathrm{CD}$ & 0.113 & 0.068 & 1.668 & 0.095 \\
\hline FD & $1.208^{* * *}$ & 0.097 & 12.411 & 0.000 \\
\hline $\mathrm{BO}$ & $0.004^{* * *}$ & 0.001 & 7.837 & 0.000 \\
\hline $\mathrm{CS}$ & $0.108^{* * *}$ & 0.017 & 6.328 & 0.000 \\
\hline $\mathrm{CA}$ & $0.154^{* * *}$ & 0.045 & 3.395 & 0.000 \\
\hline \multicolumn{2}{|c|}{ Diagnostic Test } & Statistic & Prob. & \\
\hline \multicolumn{2}{|c|}{ Adjusted $\mathrm{R}^{2}$} & 0.378 & & \\
\hline \multicolumn{2}{|c|}{ Wald-Stat } & 447.64 & 0.000 & \\
\hline \multicolumn{2}{|c|}{ Hausman Test } & 36.08 & 0.000 & \\
\hline \multicolumn{2}{|c|}{ Breusch-Pagan LM test } & 265.34 & 0.000 & \\
\hline \multicolumn{2}{|c|}{ Heteroscedasticity Test } & 3213.32 & 0.000 & \\
\hline \multicolumn{2}{|c|}{ Pesaran CSID } & 2.643 & 0.008 & \\
\hline \multicolumn{2}{|c|}{ Serial Correlation Test } & 1.869 & 0.179 & \\
\hline \multicolumn{2}{|c|}{ Observations } & 420 & & \\
\hline
\end{tabular}

Table 2: Corporate Governance, Company Size, Company Age and Sustainability Reporting

Source: Researcher's Study, 2021

Notes: Table 2 reports the feasible generalized least square (FGLS) regression results of the effects of corporate governance, company size, company age and sustainability reporting of selected quoted companies in Nigeria. The dependent variable is Sustainability Reporting (SR). The independent variables are Board Size (BS), Board Independence (BI), CEO Duality (CD), Female Director (FD), Board Ownership (BO), Company Size (CS) and Company Age (CA). Significant at $10 \%,{ }^{* *}$ Significant at $5 \%,{ }^{* * *}$ Significant at $1 \%$.

\subsection{Interpretation of Diagnostic Test}

From Table 2 above, the diagnostic test reported are the Hausman test, the Breusch and Pagan Lagrangian multiplier test, the heteroskedasticity, the Wooldridge test for autocorrelation and the Pesaran's test of cross-sectional independence, these tests were carried out so as to determine the appropriateness of the estimation technique for the specified model. First, the Hausman test was used to determine the appropriateness between the fixed effect and the random effect model. The null hypothesis of the Hausman specification test is that there is no correlation between the random effects and fixed effect model, thus the random effect estimates are efficient and consistent, and that the fixed effect estimates are inefficient. The Hausman statistic of 36.08 with a probability value of 0.00 is less than the $5 \%$ level of significance hence, the rejection of the null hypothesis. This implies that the random effect model is inefficient and inappropriate. To determine the appropriateness of the fixed effect model, there must not be presence of serial correlation and heteroscedasticity, but the results show evidence of heteroscedasticity, with a statistic of 3213.32 and it is statistically significant at 1 per cent level. The significance of the heteroscedasticity test necessitates the use of Feasible Generalized Least Square (FGLS) which corrects for serial correlation and heteroscedasticity.

To determine the cross-sectional dependence between the selected quoted companies of the study, the Pesaran CSID test was used. The statistic of 2.643 and with a probability value of 0.00 is statistically significant at $1 \%$ level of significance. This implies that the selected listed companies are cross sectional dependence. The Breusch-Pagan/CookWeisberg test for heteroscedasticity was carried out to determine if the variance of the residual is constant. The null hypothesis of homoscedasticity was rejected and the alternative hypothesis of heteroscedasticity was accepted. This was because the test statistic of 3213.32 is statistically significant at 1 per cent level. In testing for autocorrelation in the panel data, the Wooldridge test was used. The null hypothesis that the successive error terms are not correlated was not rejected because the statistic of 1.869 with a probability value of 0.179 which is greater than the $5 \%$ level of significance. Thus, the null hypothesis of no serial correlation was not rejected.

\subsection{Model of Study}

$\mathrm{SR}_{\mathrm{it}}=\alpha_{\mathrm{i}}+\beta_{1} \mathrm{BSit}+\beta_{2} \mathrm{BI}_{\mathrm{it}}+\beta_{3} \mathrm{CDit}_{+} \beta_{4} \mathrm{FD}_{\mathrm{it}}+\beta_{5} \mathrm{BO} \mathrm{it}+\beta_{6} \mathrm{CS}_{\mathrm{it}}+\beta_{7} \mathrm{CAit}+\mu_{\mathrm{it}}$

$\mathrm{SR}_{\mathrm{it}}=-1.606+0.349 \mathrm{BSit}+0.336 \mathrm{BI}_{\mathrm{it}}+0.113 \mathrm{CDit}+1.208 \mathrm{FD}_{\mathrm{it}}+0.004 \mathrm{BOit}+0.108 \mathrm{CS}$ it $+0.154 \mathrm{CAit}$

$\begin{array}{lllllll}\text { T-Test }=-10.215 & 3.283 & 2.087 & 1.668 & 12.411 & 7.837 & 6.328\end{array}$

\subsubsection{Interpretation}

Table 2 shows the results of regression analysis of the controlling effect of company size and company age on the relationship between corporate governance and sustainability reporting of selected quoted companies in Nigeria. The results show that board size, board independence, CEO duality, female director, board ownership, company size and company age have positive relationship with sustainability reporting of selected quoted companies in Nigeria. 
In addition, there is evidence that board size, board independence, female director, board ownership, company size and company age have significant relationship with sustainability reporting of selected quoted companies in Nigeria $(\mathrm{BS}=0.349$, $\mathrm{t}$-test $=3.283, p<0.05, \mathrm{BI}=0.336$, $\mathrm{t}$-test $=2.087, p<0.05, \mathrm{FD}=1.208, \mathrm{t}$-test $=12.411, p<0.05, \mathrm{~B} 0=0.004, \mathrm{t}$-test $=$ 7.837, $p<0.05, \mathrm{CZ}=0.108$, t-test $=6.328, p<0.05$ and $\mathrm{CA}=0.154$, t-test $=3.395, p<0.05$ ). This implies that board size, board independence, female director, board ownership, company size and company age are significant factors influencing changes in the sustainability reporting of selected quoted companies in Nigeria.

Conversely, there is evidence that CEO duality do not have significant relationship with the sustainability reporting of selected quoted companies in Nigeria (CD $=0.113$, t-test $=1.668, p>0.05)$. This implies that CEO duality is not significant factors influencing changes in the sustainability reporting of selected quoted companies in Nigeria.

Concerning the magnitude of the estimated parameters for the coefficients of the regression analysis, a unit increase in board size, board independence, CEO duality, female director, board ownership, company size and company age will lead to $0.349,0.336,0.113,1.208,0.004,0.108$ and 0.154 increase in the sustainability reporting of selected quoted companies in Nigeria, respectively.

The Adjusted $\mathrm{R}^{2}$ which measure the proportion of changes in the sustainability reporting of selected quoted companies in Nigeria as a result of changes in board size, board independence, female director, board ownership, CEO duality, company size and company age explains about 38 per cent changes in the sustainability reporting of selected quoted companies in Nigeria, while the remaining 62 per cent were other factors explaining changes in the sustainability reporting of selected quoted companies in Nigeria but were not captured in the model.

The Wald-Test of 447.64 is statistically significant with $p<0.05$ indicating that on the overall, the statistical significance of the model showed that the null hypothesis of company size and company age do not significantly control the relationship between corporate governance and sustainability reporting in selected quoted companies in Nigeriawas rejected. Thus, the alternative hypothesis that company size and company age significantly control the relationship between corporate governance and sustainability reporting in selected quoted companies in Nigeria was accepted.

\section{Implication of Findings}

The hypothesis of this study examined the controlling effects of company size and company age on the relationship between corporate governance (board size, board independence, CEO duality, female director and board ownership) and sustainability reporting of forty-two quoted companies in Nigeria for the period of 2010 to 2019 . The regression result of the model showed that the null hypothesis of company size and company age do not significantly control the relationship between corporate governance and sustainability reporting in selected quoted companies in Nigeriawas rejected. Thus, the alternative hypothesis that company size and company age significantly control the relationship between corporate governance and sustainability reporting in selected quoted companies in Nigeria was accepted.

As shown in the Table 2 above, the findings revealed that board size has a positive and significant relationship with sustainability reporting $(B S=0.349$, $\mathrm{t}$-test $=3.283, p<0.05)$. This implies that the larger the board size the higher the quality of SR. This conforms with the findings of previous scholars (Mojeed, et al, 2015; Ghabayen, et al, 2016 \&Yaseen, et al, 2018). Also, findings indicated that board independence has a positive and significant effect on $\mathrm{SR}(\mathrm{BI}=0.336, \mathrm{t}$-test $=$ $2.087, p<0.05)$. The higher the proportion of independent directors on board the higher the quality of SR. This conforms with previous work done by Mudiyanselage, et al, (2018) and $\mathrm{Hu}$, et al, (2018).

Conversely, there is evidence that CEO duality do not have significant relationship with the sustainability reporting of selected quoted companies in Nigeria $(C D=0.113$, t-test $=1.668, p>0.05)$. By implication the combination of chairmanship and CEO role do not promote sustainability reporting. This evidence negates previous studies that there is a negative relationship between CEO duality and SR (Al-Deen, et al, 2018; Khaldoon, et al, 2018).

There is positive and significant relationship between female directors on board and SR (FD= 1.208, t-test= $12.411, p<0.05)$. The interpretation is that the more female directors on board, the higher the quality of SR. This is supported by several studies such as Arayssi, et al, (2016), Mahmood, et al, (2018), Garcia-Sanchez, et al, (2018), Birindelli, et al, (2018) and Anazonwu, et al, (2018). However, the result of Adeniyi, et al, (2018) negates the outcome of this study by affirming that there is no significant relationship between FD and SR.

Also, there is a positive and significant relationship between board ownership and SR (BO= 0.004, t-test $=7.837$, $p<0.05)$. This implies that the higher the share ownership by the board members the higher the quality of SR. This outcome is supported by previous scholars (Rudiyanto, 2017; Masud, et al, 2018). However, the study conducted by Quadan, et al, (2019) disagreed with the findings of this study as it revealed a negative relationship between BO and SR.

The study adopted two control variables which are company size and company age. These variables are indicators for maturity of an enterprise (Mudiyanselage, et al, 2018). A firm with large total asset size and longer years of listing on NSE is expected to have sufficient capacity and experience in sustainability reporting. The Wald-Test of 447.64 is statistically significant with $p<0.05$ indicating that on the overall, the statistical significance of the model showed that company size and company age significantly control the relationship between corporate governance and sustainability reporting in selected quoted companies in Nigeria $(C Z=0.108$, t-test $=6.328, p<0.05$ and $C A=0.154, t$-test $=3.395, p<$ 0.05). The finding of this study on the controlling effect of company size is supported by previous scholars (Aliyu, 2018; Mudiyanselage, et al, 2018) 


\section{Recommendations}

The shareholders should include more female and independent directors on board so as to promote sustainability reporting practices. Also, the shareholders are advised to include more directors with share ownership as it enhances sustainability reporting practices and CEO duality should be avoided as it does not significantly impact SR.

\section{Limitation of Study}

The variables of corporate governance are limited to board size, board independence, CEO duality, female director and board ownership. Variables like risk management, audit committee size and board experience can be included in further studies. The data used for this study originated from the eleven sectors of the economy, further study can be done by comparing corporate governance and sustainability reporting in manufacturing sector with financial service sector.

\section{References}

i. Abu Qa'dan, M. B., \& Swaidan, M. S. (2019). Board composition, ownership structure and corporate social responsibility disclosure: The case of Jordan. Social Responsibility Journal, 15(1), 28-46.

ii. Adeniyi, S. I. \&Fadipe, A. O. (2018). Effect of board diversity on sustainability reporting in Nigeria: A study of beverage Manufacturing Firms. Indonesian Journal of Corporate Social Responsibility and Environmental Management, 1(1), 43-50.

iii. Ajibolade, S. O. \&Uwuigbe, U. (2013). Effect of corporate governance on corporate social and environmental disclosures in quoted companies in Nigeria. European Journal of Business and Social Sciences,2(5), 76-92.

iv. Akbas, H. E. (2016). The relationship between board characteristics and environmental disclosure: evidence from Turkish listed companies. South East European Journal of Economics and Business, 11(2), 7-19.

v. Aliyu, U. S. (2018). Board characteristics and corporate environmental reporting in Nigeria. Asian Journal of Accounting Research, 30, 1-17.

vi. Alotaibi, M. Z. M., Aburuman, N. M. \& Hussein, L. F. M. (2019). The impact of board characteristics on the level of Sustainability Practices on Jordanian listed Commercial Banks. European Journal of Scientific Research,153(4), 353-363.

vii. Anazonwu, H. O., Egbunike, F. C., \&Gunardi, A. (2018). Corporate Board Diversity on Sustainability Reporting: A Study of Selected Listed Manufacturing Firms in Nigeria. Indonesian Journal of Sustainability Accounting and Management,2(1), 65-78.

viii. Arayssi, M., Dah, M. \& Jizi, M. (2016).Women on Boards, Sustainability reporting and Firms performance. Sustainability Accounting, Management and Policy Journal, 7(3), 376-401.

ix. Beasley, M., Carcello, J. \&Hermanson, D. (1999). Preventing Fraudulent Financial Reporting. The CPA Journal, 70, 14-21.

x. Birindelli, G., Dell'Atti, S., Iannuzzi, A. P. \& Savioli, M. (2018). Composition and Activities of the Board of Directors : Impact on ESG Performance in Banking System. Sustainability, 10(4699), 1-20.

xi. Blowfield, M., \& Murray, A. (2008). Corporate responsibility: a critical introduction. Oxford; New York: Oxford university Press.

xii. Buallay, A. \& Al-Ajmi, J. (2019). The role of audit committee attributes in corporate sustainability

i. reporting: Evidence from banks in the Gulf Cooperation Council. Journal of Applied Accounting Research, 21(2), 249-264.

xiii. Carrillo, M. I. A., De La Cruz, A. M. P. \& Chicharro, M. N. (2019). Impact of Corporate Governance on Corruption Disclosure in European listed Firms through the implementation of Directive 2014/95/EU. Sustainability, 11(22), 6479.

xiv. Chang, K. \& Zhang, L. (2015).The Effects of Corporate Ownership Structure on Environmental Information Disclosure : Empirical Evidence from Unbalanced Panel Data in Heavy-Pollution Industries in China.Wseastransactions on systems and controls, 10, 405-414.

xv. Cormier, D. \&Magnan, M. (1999). Corporate environmental disclosure strategies: determinants, costs and benefits. Journal of Accounting, Auditing and Finance, 14(4), 429-451.

xvi. Cormier, D., Magnan, M. \& Van Velthoven, B. (2005). Environmental disclosure quality in large German companies: economic incentives, public pressures or institutional conditions?" European Accounting Review, 14(1), 3-39.

xvii. Dalton, C. M. \& Dalton, D. R. (2005). Boards of Directors: Utilizing Empirical Evidence in Developing Practical Prescriptions. British Journal of Management, 16, 91-97.

xviii. Dehaene, A., De Vyst, V. \&Ooghe, H. (2001). Corporate performance and board structure in Belgian companies: Long Range Plannng. International Journal of Strategic Management, 34(3), 383-398.

xix. De Villiers, C., Niker, V. \& Van Stade, C. J. (2011). The effect of board characteristics on firm environmental performance. Journal of Management, 37(6), 1636-1663.

xx. De Villiers, C., \& Marques, A. (2016). Corporate social responsibility, country-level predispositions, and the consequences of choosing a level of disclosure. Accounting and Business Research, 46(2), 167-195.

xxi. Dowling, J., \&Pfeffer, J. (1975). Organizational legitimacy: social values and organizational behaviour. The Pacific Sociological Review, 18(1), 122-145.

xxii. Dyllick, T. \&Hockerts, K. (2002). Beyond the Business Case for Corporate Sustainability. University of St. Gallen. 11.10. 1002/bse.323. 
xxiii. Fama, E. F. \& Jensen M. C. (1983). Seperation of ownership and control. The Journal of Law and Economics, 26(2), 301-325.

xxiv. Ghabayen, M. A., Mohamad, N. R. \& Ahmad N. (2016). Board Characteristics and Corporate Social Responsibility Disclosure in the Jordanian Banks. Corporate Board: Role, Duties \&Composition, 12(1), 84-100.

xxv. Ghazali, N. A. M. (2010). Ownership structure, corporate governance and corporate performance in Malaysia. International Journal of Commerce and Management, 20(2), 109-119.

xxvi. Gitzmann, V. 0. (2008). An information economics analysis of financial reporting and external auditing. The Accounting Review, 53(4), 910-920

xxvii. Gray, R., Kouhy, R. \& Lavers, S. (1995). Corporate Social \&Enviromental Reporting; A review of the Literature and a Longitudinal Study of U.K. Disclosure. Accounting, Auditing \& Accountability Journal, 8(2), 47-77.

xxviii. Gutrie, J. \& Parker, L. D. (1989). Corporate Social Reporting: A rebuttal of legitimacy theory. Accounting and Business Research, 19(76), 343-352.

xxix. Habbash, M. (2016). Corporate governance and corporate social responsibility disclosures: Evidence from Saudi Arabia. Social Responsibility Journal, 12(4), 740-754.

xxx. Hahn, R. \&Kuhnen, M. (2013). Determinants of sustainability reporting: a review of results, trends, theory, and opportunities in an expanding field of research. Journal of Cleaner Production, 59, 5-21.

xxxi. Hassanein, A. \&Hussainey, M, (2015). Is forward-looking financial disclosure really informative? Evidence from UK narrative statements. International Review of Financial Analysis, 41(5), 52-61.

xxxii. Herda, D. N., Taylor, M. E. \&Winterbotham, G. (2012). The effect of board independence on the sustainability reporting practices of large U.S. firms. Social and Environmental Accounting, 6(3-4), 178-197.

xxxiii. Hermalin, B. E. \&Weisbach, M. S. (2003). Board of Directors as an Endogenously Determined Institution: A Survey of the Economic Literature. Center for Responsible Business. Working Paper Series. Paper 3

xxxiv. Ho, Ch.k. (2005). Corporate Governance and Competitiveness: An International analysis. Corporate Governance: An international review, 13(2), 211-253.

xxxv. Hooghiemstra, R. (2000). Corporation communication and impression management: New perspectives on why companies engage corporate social reporting. Journal of Business Ethics, 27, 55-68.

xxxvi. Hu, M. \&Loh, L. (2018). Board Governance and Sustainability Disclosure: A cross Sectional Study of SingaporeListed Companies. Journal of sustainability, 2578, 1-14.

xxxvii. Hyun, E., Yang, D., Jung, H. \& Hong, K. (2016). Women on board and corporate social responsibility. Sustainability, 8, 300.

xxxviii. Ilaboya, O. J., Ohiokha, G. \&Izevbekhai, M. O. (2016). Determinants of board size and composition: a comparative study of Nigerian and Malaysian quoted companies. Ekon. Misao I PraksaDbk. GOD, 25(2), 423-44.

xxxix. Isa, M. A. (2014). Sustainability Reporting among Nigeria Food and Beverages Firms. International Journal of Agriculture and Economic Development, 2(1), 1-9.

xl. Isik. O. \&Ince, A. R. (2016). Board size, board composition and performance: An investigation in Turkish banks. International Business Research, 9(2), 74-83.

xli. Jensen, M. C. \&Meckling, W. (1976). Theory of the firm: managerial behaviour, agency costs and ownership structure. Journal of Financial Economics, 3(3), 305-360.

xlii. Kapotas, P. (2010). Gender quotas in politics; The Greek system in the light of EU law. Eur. Law Journal, 16: 2946.

xliii. Kesner, I. F. \& Johnson, R. B. (1990). An investigation of the relationship between board composition and stockholder suits. Strategic Management Journal, 11(4), 327-336.

xliv. Khaldoon, .D., Dea'a Al-Deen, O. A. \& Mahmoud, M. A. (2018). Does CEO Duality and Family Concentration Hinder the Effectivenss of the Corporate Board of Directors in Jordanian Service Firms? Journal of Environmental Accounting and Management, 6(2), 95-104.

xlv. Kokmanova, A., Hrebicek, J. \&Docekalova, M. (2011). Corporate Governance and sustainability reporting. Economics and Management, 16, 543-550.

xlvi. Krechovska, M. \&Prochavzkova, P. T. (2014). Sustainability and its integration into corporate governance focusing on corporate performance management and reporting. Procedia Engineering, 69, 1144-1151.

xlvii. Lakhal, F. (2005). Voluntary earnings disclosures and corporate governance: evidence from

a. France. Review of Accounting \& Finance, 4, 64-86.

xlviii. Larcker, D. F., Richardson, S. A. \& Tuna, I. (2007). Corporate governance, accounting outcomes and organizational performance. The Accounting Review, 82(4), DOI: 10.2308/accr.2007.82.4.963.

xlix. Liao, L., Luo, L. \& Tang, Q. (2015). Gender diversity, board independence, environmental committee and greenhouse gas disclosure. British Accounting Review, 47(4),

i. 409-424.

l. Lindbloom, C. K. (1993). The Implication of Organization Legitimacy for Corporate Social Performance and Disclosure. Paper presented at the Critical Perspectives in Accounting Conference, New York.

li. Ling, C. \& Sultana, N. (2015). Corporate social responsibility what motivates management to disclose? Social Responsibility Journal, 11(3), 513-534.

lii. Lipton, M. \&Lorsch, J. W. (1992). A Modest Proposal for Improved Corporate Governance. Business Lawyer, $48(1), 59-77$. 
liii. Majeed, S., Aziz, T. \&Saleem, S. (2015). The Effect of Corporate Governance Elements on Corporate Social Responsibility (CSR) Disclosure: Empirical Evidence from Listed Companies at KSE Pakistan. International Journal of Financial Studies, 3, 530 - 556.

liv. Mahmood, Z., Kouser, R., Ali, W., Ahmad, Z., \& Salman, T. (2018). Does Governance Affect Sustainability Disclosure? A Mixed Methods Study. Sustainability, 10, 207; 10:3390/su10010207.

lv. Mallette, P. \& Fowler, K. L. (1992). Effect of board composition and stock ownership on adoption of "poison pills". Academic Management Journal, 35, 1010-1035.

lvi. Masud, M. K., Nurunnabi, M., \& Bae, S. M. (2018). The effects of corporate governance on environmental sustainability reporting; empirical evidence from South Asian countries. Asian Journal of Sustainability and Social Responsibility, 3(1), 1-26.

lvii. Michelon, G. \&Parbonetti, A. (2012). The effect of corporate governance on sustainability disclosure. Journal of Management and Governance, 16(3), 1-33.

lviii. Mobus, J. L. (2005). Mandatory environmental disclosures in a legitimacy theory context. Accounting, Auditing and Accountability, 18(4), 492-517.

lix. Mudiyanselage, R., \&Swarnapali, N. C. (2018). Board involvement in corporate sustainability reporting: Evidence from Sri Lanka. Corporate Governance: International Journal of Business in Society, 18(6), $1042-1056$.

lx. Naseer, M., \& Rashid, K. (2018). The relationship between environmental reporting and corporate governance: empirical evidence from Pakistan. In book: Globalization. DOI: 10.5772/intechopen.75228

lxi. Nazari, J. A., Herremans, I. M. \& Warsame, H. A. (2015). Sustainability reporting: externalmotivators and internal facilitators. Corporate Governance, 15(3), 375-390.

lxii. Ngakwe, C. C., Ganda, F. \& Akinyomi, O. J. (2014). Independent board of directors and corporate sustainability: A south African and Nigerian Perspective. Journal of Governance and Regulation,3(1), 58-68.

lxiii. Nyahas, S. I., Ntayi, J. M., Kamukama, N., \&Munene, J. (2018). Stakeholders' influence on voluntary disclosure practices by listed companies in Nigeria. International Journal of Law and Management, 60(2), 267-283.

lxiv. Odoemelam, N. \&Okafor, R. G. (2018). The Influence of Corporate Governance on Environmental Disclosure of Listed Non-Financial Firms in Nigeria. Indonesian Journal of Sustainability Accounting and Management, 2(1), 25-49.

lxv. Ong, T. \&Djajadikerta, H. G. (2018). Corporate governance and sustainability reporting in the Australian resources industry: an empirical analysis. Social Responsibility Journal, 1-13.

lxvi. Patten, D. M. (1992). Intra-industry environmental disclosures in response to the Alaskan oil spill: a note on legitimacy theory. Accounting, Organizations and Society, 17(5), 471-475.

lxvii. Patten, D. M. (2002). The relation between environmental performance and environmental disclosure: a research note. Accounting, Organizations and Society, 27(8), 763-773.

lxviii. Perrini, F. \&Tencati, A. (2006). Sustainability and stakeholder management: the need for new corporate performance evaluation and reporting systems. Business Strategy and the Environment, 15(5), 296-308.

lxix. Pickering, H. A. (2011). Facors that influence the audit report lag. Journal of Business and Accountancy, 12(2), 97-106.

Ixx. Rahman, M. A. \& Islam, J. (2018). The Impact of Corporate Governance on Bank Performance: Empirical Evidence from Bangladesh. Global Journal of Management and Business Research, 18(8), 1-8.

lxxi. Rechner, P. L. \& Dalton, D. R. (1991). CEO duality and organizational performance: A longitudinal analysis. Strategic Management Journal, 12(2),155-160.

lxxii. Rudyanto, A. (2017). State Ownership, Family Ownership and Sustainability Report Quality: The Moderating Role of Board Effectiveness. Accounting and Finance Review, 2(2), 15-25.

lxxiii. Rudyanto, A. \&Siregar, S. V. (2018). The effect of stakeholder pressure and corporate governance on the sustainability report quality. International Journal of Ethics and Systems, 34(2), 233-249.

lxxiv. Saheen, S. \& Malik, O. A. (2012). The impact of capital intensity, size of firm and profitability on debt financing in textile industry in Pakistan. Interdisciplinary Journal of Contemporary Research in Business, 3(10), 10611066.

lxxv. Samaha, K., Khlif, H. \&Hussainey, K. (2015). The impact of board and audit committee characteristics on voluntary disclosure: A meta-analysis. Journal of International Accounting, Audit \& Tax, 24, 13-28.

lxxvi. Sar, A. K. (2018). Impact of corporate governance on sustainability reporting: A study of the Indian FCMG industry. Academy of Strategic Management Journal, 17(1),

lxxvii. Sawani, Y., Zain, M. M. \&Darus, F. (2010). Preliminary insights on sustainability reporting and assurance practices in Malaysia. Social Responsibility Journal, 6, 627-645.

lxxviii. Schaltegger, S., \& Burritt, R. L. (2010). Sustainability accounting for companies: catchphrase or decision support for business leaders? Journal of World Business, 45, 375-384.

lxxix. Schaltegger, S., Etxeberria, I. \&Ortas, E. (2017). Innovating corporate accounting and reporting for sustainability- attributes and challenges. Sustainable Development,25(2), 113-122.

Ixxx. Shuaibu, K., Ali, I. \& Amin, I. (2019). Company attributes and firm value of listed consumer goods company in Nigeria. Journal of Research in Humanities and Social Sciences, 7(5), 40-49.

lxxxi. Shumway, T. (2001). Forecasting bankruptcy more accurately: a simple hazard model. The Journal of Business, 74(1), 101-124.

lxxxii. Steger, U., \&Amann, W. (2008). Corporate governance: how to add value. John Wiley \& Sons. 
lxxxiii. Sustentare (2010). Sustainability Governance: Portuguese Companies in an International context. Retrieved on $25^{\text {th }}$ February, 2020 from www.http://www.sustentare.pt/pdf/doc.suste+sam(ENG1).pdf

lxxxiv. Villier, C., Naiker, V. \&Staden, C. J. (2011). The effect of board characteristics on firm environmental performance. Journal of Management,

lxxxv. Vinasithamby, S. (2015). Does firm size influence profitability? Evidence from Listed Hotels and Travels sector of Sri Lankan sectors. Research Journal of Finance, 6(6), 201-207.

lxxxvi. Waddock, S. A. \& Graves, S. B. (1997). The corporate social performance-financial performance link. Strategic Management Journal, 18(4), 303-319.

lxxxvii. Wang, J. \& Dewhirst, H. D. (1992). Boards of directors and stakeholders' orientation. Journal of Business Ethics, $11,115-123$.

lxxxviii. Wang, L., \& Lin, L. (2007). A methodological framework for the triple bottom line accounting and management of industry enterprises. International Journal of Production Research, 45(5), 1063-1088.

lxxxix. Wijethilake, C., Ekanayake, A. \&Perera, S. (2015). Board involvement in corporate performance: evidence from a developing country. Journal of Accounting in Emerging Economies,5(3), 250-268. 